Published in final edited form as:

Pharmacogenomics. 2010 July ; 11(7): 1003-1010. doi:10.2217/pgs.10.95.

\title{
Irinotecan pharmacogenomics
}

\author{
Sharon Marsh ${ }^{\dagger}$ and Janelle M Hoskins ${ }^{1}$ \\ ${ }^{1}$ UNC Institute for Pharmacogenomics \& Individualized Therapy, Eshelman School of Pharmacy, \\ University of North Carolina, Chapel Hill, NC, USA
}

\begin{abstract}
Irinotecan is a camptothecin analog used as an anticancer drug. Severe, potentially life-threatening toxicities can occur from irinotecan treatment. Although multiple genes may play a role in irinotecan activity, the majority of evidence to date suggests that variation in expression of UGT1A1 caused by a common promoter polymorphism $(U G T 1 A l * 28)$ is strongly associated with toxicity; however, this link is dose dependent. Variations in other pharmacokinetic genes, particularly the transporter $A B C C 2$, also contribute to irinotecan toxicity. In addition, recent studies have shown that pharmacodynamic genes such as TDPI and XRCCl can also play a role in both toxicity and response.
\end{abstract}

\section{Keywords}

ABCC2; irinotecan; pharmacogenomics; TDP1; toxicity; UGT1A1; XRCC1

Camptothecin, a cytotoxic agent found in Camptotheca acuminata, was developed as an anticancer agent in the early 1970s [1-3]. Its mechanism of action is to bind to the DNA/ topoisomerase I complex during DNA replication, preventing the resealing of single-strand breaks. Ultimately, the replication machinery collides with the camptothecin/toposiomerase I complex, shattering the DNA [4]. However, camptothecin is insoluble and attempts to address this both reduced the efficacy and increased the toxicity of the drug.

Camptothecin analogs were developed in the 1990s to circumvent the solubility problems. Irinotecan (also known as CPT-11, Camptosar ${ }^{\circledR}$ ) is an analog approved for first-line therapy of advanced colorectal cancer in combination with 5-fluorouracil and/or leucovorin. In addition, irinotecan/cisplatin combination therapy is used for other cancers, for example lung and ovarian [5-6]. Recent studies have involved the combination of irinotecan with bevacizumab or cetuximab [1-2,7-8].

Diarrhea and neutropenia are major limiting factors for irinotecan, with up to $36 \%$ of patients experiencing severe, potentially life-threatening toxicities [9]. Methods such as pharmacogenomics to prospectively screen patients for DNA variations (Table 1) prior to selecting irinotecan therapy or dose would help improve patient care and reduce healthcare costs [10-12].

\footnotetext{
(C) 2010 Future Medicine Ltd

${ }^{\dagger}$ Author for correspondence: Faculty of Pharmacy \& Pharmaceutical Sciences, 3126 Dentistry/Pharmacy Centre, University of Alberta, Edmonton, AB T6G 2N8, Canada Tel.: +1 7804922266 Fax: +1 7804921217 smarsh@ pharmacy.ualberta.ca.

The authors have no other relevant affiliations or financial involvement with any organization or entity with a financial interest in or financial conflict with the subject matter or materials discussed in the manuscript apart from those disclosed.

No writing assistance was utilized in the production of this manuscript.
} 


\section{Irinotecan pharmacokinetics}

\section{Metabolism}

Irinotecan is a prodrug, metabolized into the active form, SN-38, via human carboxylesterases CES1 and CES2. CYP3A4 converts irinotecan into the inactive metabolite, APC. The active SN-38 can be subsequently inactivated through glucuronidation via members of the UDP-glucuronosyltransferase family [12]. UGT1A enzymes are a product of alternative splicing from the UGT1A locus located on chromosome 2q37. A total of 13 UGTIA genes are encoded at this locus (including four pseudogenes). Each UGT1A enzyme has a unique promoter and a unique exon 1, while the remaining four exons are shared with all members of the UGT1A family [13].

\section{Metabolism pharmacogenomics}

Carboxylesterases-Carboxylesterase 2 is the key enzyme responsible for hydrolyzing CPT-11 to the active $\mathrm{SN}-38$ form [14]. CES2 expression is highly variable among individuals [15-16], and in vitro studies suggest that increased CES2 expression leads to increased irinotecan metabolism [17]. However, extensive assessment of the CES2 gene did not identify any functional polymorphisms [18-19], and characterization of a common promoter variant in the $5^{\prime}$-UTR of $C E S 2$ (referred to as $830 \mathrm{C}>\mathrm{G}$; located at $-171 \mathrm{C}>\mathrm{G}$ ) did not identify any associations with CES2 expression or catalytic activity, or irinotecan toxicity or outcome [20]. CES2 is, however, controlled by three distinct promoter regions [21], and it is possible that control of promoter choice may explain some of the individual variation in CES2 expression.

CES1 plays a minor role in irinotecan metabolism, and extensive resequencing of CES1 also did not identify any functional polymorphisms [18]. However, in a Japanese hypertensive patient population, a $-816 \mathrm{~A}>\mathrm{C}$ variant in the $C E S 1$ promoter region has been reported to affect $C E S 1$ promoter activity [22], but this remains to be assessed in the context of irinotecan metabolism.

CYP3A4-CYP3A4 inactivates irinotecan through conversion into the metabolite APC [23]. While there is no evidence of variants in the CYP3A4 gene providing a useful screen for APC conversion, the interindividual variability in CYP3A4 activity can be exploited for irinotecan dosing [24].

UGT1A1-The most comprehensively studied genetic marker linked to toxicity from irinotecan therapy is found in the UDP-glucuronosyltransferase gene, UGT1A1. The UGT1A1 enzyme is responsible for hepatic bilirubin glucuronidation, and reduced UGT1A1 expression leads to Gilbert's syndrome [25]. Expression of UGT1A1 is, in part, controlled by a polymorphic dinucleotide repeat within the UGTIAl promoter TATA element consisting of between five and eight copies of a TA repeat ([TA $]_{n}$ TAA), with the (TA) 6 TAA allele the most common (considered wild-type) and (TA) ${ }_{7}$ TAA the most frequently recorded variant allele (usually denoted $U G T 1 A 1 * 28$ ) [26]. The longer the repeat allele, the lower the corresponding UGTIAl gene expression, with patients carrying the (TA) 7 TAA and (TA $)_{8}$ TAA alleles having significantly lower UGT1A1 expression. The frequency of the UGTIA $* 28$ allele has been assessed worldwide and ranges from approximately $15 \%$ in Asians to $45 \%$ in Africans. It is also found in 26-38\% of Caucasians, African-Americans and Hispanics [27-29]. As increasing the number of TA repeats decreases UGT1A1 expression, the presence of more than six TA repeats in the UGTIAl promoter region leads to reduced glucuronidation, including reduced $\mathrm{SN}-38 \mathrm{G}$ formation. This results in an excess build-up of SN-38, leading to toxicity $[12,25,30]$. 
Early studies confirmed the link between $U G T 1 A 1 * 28$ and irinotecan toxicity, specifically diarrhea and neutropenia [27,31], and a retrospective analysis of DNA from 524 metastatic colorectal cancer patients on the N9741 study also associated $U G T 1 A l * 28$ with the incidence of toxicities (neutropenia, febrile neutropenia and vomiting) [32]. Furthermore, a prospective study of 66 patients with advanced disease treated with irinotecan found that patients homozygous for $U G T 1 A 1 * 28$ had a significantly greater risk of grade IV neutropenia compared with patients with at least one wild-type allele [33].

UGT1A1 in the clinic-In 2005, the US FDA approved a genetic test for UGT1AI*28 [34] and altered the irinotecan package insert to include toxicity and dosing warnings relating to the $U G T 1 A 1 * 28$ allele [35]. This marked a significant step towards incorporating pharmacogenomics into clinical practice. However, 5 years on, concerns still remain over the specific irinotecan dose required based on genotype [36-37]. A subsequent study has identified that the relationship between $U G T 1 A 1 * 28$ and irinotecan toxicity is dependent on the irinotecan regimen used, rendering $U G T 1 A 1 * 28$ unsuitable as a marker for toxicity with lower doses $\left(50-180 \mathrm{mg} / \mathrm{m}^{2}\right)$. For moderate-to-high doses $\left(200-350 \mathrm{mg} / \mathrm{m}^{2}\right)$, the risk of severe hematological toxicity in patients homozygous for $U G T 1 A 1 * 28$ is 27.8 -times higher than for patients with at least one wild-type allele [38]. Furthermore, a European study confirmed that toxicity from low-dose irinotecan was not affected by the UGTIAI*28 variant [39]. Consequently, it appears necessary to further amend the irinotecan package insert to include dose/genotype guidelines. A recent prospective European study of 59 patients showed that when $U G T 1 A 1 * 28$ homozygous patients are excluded; the standard 180 $\mathrm{mg} / \mathrm{m}^{2}$ dose is significantly lower than the irinotecan dose that can be tolerated [40]. Dosing information from a Japanese Phase I study of 27 patients receiving irinotecan and doxifluridine has suggested a starting dose of $70 \mathrm{mg} / \mathrm{m}^{2}$ for patients heterozygous for $U G T 1 A 1 * 28$. No homozygous patients were identified in this study [41].

Other UGT1A1 polymorphisms-There are other significant polymorphisms in the UGT1Al gene. Patients with haplotypes containing both the $-3156 \mathrm{G}>\mathrm{A}$ variant and $U G T 1 A 1 * 28$ experienced significantly higher incidence of severe neutropenia compared with patients with haplotypes not containing $-3156 \mathrm{G}>\mathrm{A}$ [33], and in the N9741 study the UGT1A1 -3156 variant was associated with a significantly increased risk of neutropenia [32]. In Caucasian populations, the $* 28$ and -3156 alleles are in strong linkage disequilibrium [33].

In Asian populations where the frequency of $U G T 1 A 1 * 28$ is low [42], other UGT1A1 variants can also play a role in irinotecan toxicity $[12,43-50]$. For example, in Korean patients with non-small-cell lung cancer treated with irinotecan-containing therapy, there were associations between the exon 1 polymorphism $U G T 1 A l * 6(\mathrm{G} 71 \mathrm{R})$, irinotecan pharmacokinetics, and toxicity from irinotecan therapy [47]. In a further study of 88 Japanese cancer patients receiving irinotecan, two haplotype groups were associated with reduced area under the curve (AUC) ratios of SN-38G to SN-38, which is predicted to have an effect on irinotecan toxicity. These haplotypes were denoted $* 28$ (containing the UGT1AI $* 28$ allele) and $* 6$ (containing the exon $1 \mathrm{G} 71 \mathrm{R}$ polymorphism) [44]. Patients with the $* 6$ haplotype alone did not show significant variation in their AUC ratios; however, patients with one $* 6$ haplotype and one $* 28$ haplotype had significantly lower AUC ratios compared with patients with homozygous wild-type UGTIA1 [44].

Other UGT1A genes-Variants in UGTIA7 and UGTIA9 are also associated with SN-38 glucuronidation [51] and irinotecan toxicities (particularly diarrhea) [47,52,53], although these studies require further exploration. UGTIA7*3 has been associated with hematologic toxicity in metastatic colorectal cancer patients treated with irinotecan [54]. Furthermore, 
$U G T 1 A 7 * 2$ and $* 3$, as well as $U G T 1 A 9-118(\mathrm{dT})$ alleles, were associated with response to irinotecan [52].

\section{Transport}

Irinotecan and $\mathrm{SN}-38$ may be transported out of the cell via members of the ATP-binding cassette transporter family [55], specifically ABCB1 (MDR1; P-glycoprotein), ABCC2 (CMOAT; MRP2) and ABCG2 (BCRP). In addition, glucuronidated SN-38 can be removed from the cell by ABCC2 (Figure 1).

\section{Transport pharmacogenomics}

ABCB1-In 65 patients treated with irinotecan, the common $A B C B 1$ 1236C $>\mathrm{T}$ variant caused significantly decreased clearance of irinotecan [56]. ABCB1 3435C $>\mathrm{T}$ was associated with diarrhea caused by irinotecan-containing therapy in a subset of 87 patients from a Phase III small-cell lung cancer trial [57]. In a further study, a haplotype containing the three most commonly studied $A B C B 1$ polymorphisms $(1236 \mathrm{C}>\mathrm{T}, 2677 \mathrm{G}>\mathrm{T}$ and $3435 \mathrm{C}>\mathrm{T}$ ) was associated with reduced renal clearance in 49 Asian patients receiving irinotecan [58]. The $A B C B 1$ haplotype was also associated with response and survival in 140 colorectal cancer patients from the Nordic VI trial [59]. In the same study, $A B C B 13435 \mathrm{C}>\mathrm{T}$ was also predictive of early toxic events [59].

ABCC2 - In 64 patients with solid tumors treated with irinotecan, a significant correlation was observed with irinotecan and metabolite clearance, and the 3972T $>\mathrm{C}$ polymorphism [43], which was also associated with toxicity [60]. ABCC2 -24T homozygotes and 3972T homozygotes also experienced significantly better response rates and progression-free survival in non-small-cell lung cancer patients receiving irinotecan and cisplatin [61]. In addition, a haplotype in the multidrug transporter $A B C C 2$ is associated with toxicity in patients lacking $U G T 1 A 1 * 28$ [46,62-63], suggesting that this haplotype could be a secondary screen for patients who are wild-type for UGT1Al, to further reduce the risk of toxicity.

ABCG2-Cell lines overexpressing ABCG2 are resistant to several topoisomerase I inhibitors, including irinotecan [64] and SN-38 [65]. The $A B C G 2$ variant $421 \mathrm{C}>\mathrm{A}(\mathrm{Q} 141 \mathrm{~K})$ reduced $A B C G 2$ gene expression and caused irinotecan resistance in cancer cell lines [66] and neutropenia in 55 patients receiving irinotecan monotherapy when assessed as a haplotype with $A B C G 2$ IVS12 +49G>T [67]. Alone, the $A B C G 2421 \mathrm{C}>\mathrm{A}$ variant was not associated with toxicity $[49,61]$. A further polymorphism, $A B C G 234 \mathrm{G}>\mathrm{A}$, was significantly associated with diarrhea in 107 cancer patients [60] but was not associated with toxicity or outcome in 107 non-small-cell lung cancer patients [61].

\section{Irinotecan pharmacodynamics}

Topoisomerase I is the target for $\mathrm{SN}-38$, and several downstream genes have been associated with camptothecin sensitivity, and are consequently included in the irinotecan pathway (Figure 1) including XRCC1 [68], ADPRT [69], TDP1 [70], CDC45L [71] and NF$\kappa B 1[72-73]$.

\section{Pharmacodynamics \& pharmacogenomics}

A retrospective analysis of 107 colorectal cancer patients identified a significant association with TDPI IVS12+79T>G and grade 3/4 neutropenia, and the TDP1 variant and an XRCC1 haplotype and response to irinotecan [74]. Associations with toxicity were not seen in a follow-up study of 85 cancer patients [75], although the dose of irinotecan was higher (300$350 \mathrm{mg} / \mathrm{m}^{2}$ compared with a median of $180 \mathrm{mg} / \mathrm{m}^{2}$ in [74]), and no significant association 
with $X R C C 1 \mathrm{R} 399 \mathrm{Q}$ and toxicity was seen in 18 colorectal cancer patients [76]. However, the variant $X R C C 1 \mathrm{R} 399 \mathrm{Q}$ was associated with overall survival in 43 Turkish metastatic colorectal cancer patients [77]. Assessment of irinotecan pharmacodynamics in the context of pharmacogenomics is in its infancy, and subsequent validation experiments are required.

\section{Future perspective}

Toxicity is a major dose-limiting, life-threatening side effect from irinotecan chemotherapy. There are comprehensive data to suggest that $U G T 1 A l * 28$ may provide a genetic marker that patients can be screened for prior to irinotecan therapy and/or dose selection, and this has the potential to be a cost-effective screening approach [78]. However, a decade on from the initial association with toxicity, there are still questions remaining about how to interpret the genetic information [37]. Moreover, UGTIAI $* 28$ does not account for all the toxicity seen from irinotecan therapy. Consequently, although screening for this allele can identify patients at risk, the lack of $U G T 1 A I * 28$ does not preclude the chances of a patient experiencing severe toxicity.

Alongside variants in other UGTIA genes, transporters, and pharmacodynamic genes (Table 1), in vitro studies have shown that altered expression of PXR (encoded by the NRII2 gene) can affect SN-38 glucuronidation [79]. Consequently, variation in the NRII2 gene should be explored in the context of irinotecan therapy. Recent work has also suggested that epigenetic factors, such as methylation, may also play a role in altering UGT1A1 expression [80], and it is possible that screening of the tumor cells as well as germline DNA may also be needed for a comprehensive irinotecan pharmacogenomic profile.

\section{Conclusion}

Although $U G T 1 A I * 28$ provides a compelling story for irinotecan toxicity, it is not the only answer. Variation in any gene involved in the irinotecan pathway (Figure 1) could play a role in either toxicity or response. As well as polymorphisms, either assessed singly or in the form of a haplotype, other genomic alterations, such as epigenetics, also need to be assessed to build a comprehensive pharmacogenomic profile. This may require assessing DNA from tumor tissue to analyze specific alterations in the tumor genome, alongside the more typical germline DNA screening. Currently, markers for irinotecan response are few, and many remain unvalidated. Further analysis, particularly of the pharmacodynamic genes, will hopefully identify the genetic basis of response to irinotecan.

\section{Executive summary}

- Irinotecan is approved, in combination, for the treatment of metastatic colorectal cancer. It is also used for treating other solid tumors such as ovarian and non-small-cell lung cancer.

- Severe toxicity from irinotecan occurs in up to $36 \%$ of patients.

\section{Irinotecan pharmacokinetics}

- A polymorphic dinucleotide repeat in the UGT1Al promoter region $\left(U G T 1 A l^{*} 28\right)$ is significantly associated with irinotecan toxicity.

- There is now a US FDA-approved test for $U G T 1 A 1 * 28$, and the irinotecan package insert contains warnings about $U G T I A I * 28$ and risk of toxicity.

- The $U G T 1 A 1 * 28$ association with irinotecan toxicity is dose dependent.

- Other UGTIA polymorphisms may also play a role in irinotecan toxicity, especially in populations with a low incidence of $U G T 1 A 1 * 28$. 
- $A B C B 1$ polymorphisms have been associated with both toxicity and response.

- An $A B C C 2$ haplotype may predict irinotecan toxicity in patients who are not carriers of $U G T 1 A 1 * 28$.

Irinotecan pharmacodynamics

- Initial studies have shown that XRCC1 and TDP1 are associated with toxicity and response.

\section{Future perspective}

- Phase I studies aimed at determining $U G T 1 A 1 * 28$-dependent dosing of irinotecan will help to improve the use of irinotecan pharmacogenomics in clinical practice.

- Other pharmacogenomic studies, including expression panels and epigenetic markers, may prove to be useful indicators of outcome and toxicity to irinotecan.

\section{Conclusion}

- Although $U G T 1 A 1 * 28$ is a strong candidate as a pharmacogenomic marker for irinotecan toxicity, a panel of markers will be required in order to be as predictive as possible prior to irinotecan therapy selection or irinotecan dose selection.

\section{Acknowledgments}

Financial \& competing interests disclosure Sharon Marsh is supported by the University of Alberta, Janelle M Hoskins is supported by the NIH Pharmacogenetics Research Network grant U01GM63340.

\section{Bibliography}

Papers of special note have been highlighted as:

a of considerable interest

1. Abang AM. The clinical pharmacology of topoisomerase I inhibitors. Semin. Hematol 1998;35(3 Suppl. 4):13-21. [PubMed: 9779877]

2. Rothenberg ML. The current status of irinotecan (CPT-11) in the United States. Ann. NY Acad. Sci 1996;803:272-281. [PubMed: 8993521]

3. Wall ME. Camptothecin and taxol: discovery to clinic. Med. Res. Rev 1998;18(5):299-314. [PubMed: 9735871]

4. Lavelle F, Bissery MC, Andre S, Roquet F, Riou JF. Preclinical evaluation of CPT-11 and its active metabolite SN-38. Semin. Oncol 1996;23(1 Suppl. 3):11-20. [PubMed: 8633248]

5. Devore R 3rd, Johnson D, Crawford J, Dimery I, Eckardt J, Eckhardt SG. Irinotecan plus cisplatin in patients with advanced non-small-cell lung cancer. Oncology (Williston Park) 1998;12(8 Suppl. 6): 79-83. [PubMed: 9726097]

6. Gershenson DM. Irinotecan in epithelial ovarian cancer. Oncology (Williston Park) 2002;16(5 Suppl. 5):29-31. [PubMed: 12109803]

7. Hurwitz H, Fehrenbacher L, Novotny W, et al. Bevacizumab plus irinotecan, fluorouracil, and leucovorin for metastatic colorectal cancer. N. Engl. J. Med 2004;350(23):2335-2342. [PubMed: 15175435]

8. Hoff PM, Pazdur R. Progress in the development of novel treatments for colorectal cancer. Oncology 2004;18(6):705-708. [PubMed: 15214591] 
9. Fuchs CS, Moore MR, Harker G, Villa L, Rinaldi D, Hecht JR. Phase III comparison of two irinotecan dosing regimens in second-line therapy of metastatic colorectal cancer. J. Clin. Oncol 2003;21(5):807-814. [PubMed: 12610178]

10. Evans WE, McLeod HL. Pharmacogenomics - drug disposition, drug targets, and side effects. N. Engl. J. Med 2003;348(6):538-549. [PubMed: 12571262]

11. Marsh S, McLeod HL. Cancer pharmacogenetics. Br. J. Cancer 2004;90(1):8-11. [PubMed: 14710198]

12. Marsh S, McLeod HL. Pharmacogenetics of irinotecan toxicity. Pharmacogenomics 2004;5(7): 835-843. [PubMed: 15469406]

13. Gong QH, Cho JW, Huang T, et al. Thirteen UDP glucuronosyltransferase genes are encoded at the human UGT1 gene complex locus. Pharmacogenetics 2001;11(4):357-368. [PubMed: 11434514]

14. Humerickhouse R, Lohrbach K, Li L, Bosron WF, Dolan ME. Characterization of CPT-11 hydrolysis by human liver carboxylesterase isoforms hCE-1 and hCE-2. Cancer Res 2000;60(5): 1189-1192. [PubMed: 10728672]

15. Xu G, Zhang W, Ma MK, McLeod HL. Human carboxylesterase 2 is commonly expressed in tumor tissue and is correlated with activation of irinotecan. Clin. Cancer Res 2002;8(8):26052611. [PubMed: 12171891]

16. Zhang W, Xu G, McLeod HL. Comprehensive evaluation of carboxylesterase-2 expression in normal human tissues using tissue array analysis. Appl. Immunohistochem. Mol. Morphol 2002;10(4):374-380. [PubMed: 12607608]

17. Yano H, Kayukawa S, Iida S, et al. Overexpression of carboxylesterase-2 results in enhanced efficacy of topoisomerase I inhibitor, irinotecan (CPT-11), for multiple myeloma. Cancer Sci 2008;99(11):2309-2314. [PubMed: 18771527]

18. Marsh S, Xiao M, Yu J, et al. Pharmacogenomic assessment of carboxylesterases 1 and 2. Genomics 2004;84(4):661-668. [PubMed: 15475243]

19. Charasson V, Bellott R, Meynard D, Longy M, Gorry P, Robert J. Pharmacogenetics of human carboxylesterase 2, an enzyme involved in the activation of irinotecan into SN-38. Clin. Pharmacol. Ther 2004;76(6):528-535. [PubMed: 15592324]

20. Bellott R, Le Morvan V, Charasson V, et al. Functional study of the $830 \mathrm{C}>\mathrm{G}$ polymorphism of the human carboxylesterase 2 gene. Cancer Chemother. Pharmacol 2008;61(3):481-488. [PubMed: 17483951]

21. Wu MH, Chen P, Remo BF, Cook EH Jr, Das S, Dolan ME. Characterization of multiple promoters in the human carboxylesterase 2 gene. Pharmacogenetics 2003;13(7):425-435. [PubMed: 12835618]

22. Geshi E, Kimura T, Yoshimura M, et al. A single nucleotide polymorphism in the carboxylesterase gene is associated with the responsiveness to imidapril medication and the promoter activity. Hypertens Res 2005;28(9):719-725. [PubMed: 16419644]

23. Haaz MC, Rivory L, Riche C, Vernillet L, Robert J. Metabolism of irinotecan (CPT-11) by human hepatic microsomes: participation of cytochrome P-450 3A and drug interactions. Cancer Res 1998;58(3):468-472. [PubMed: 9458091]

24. van der Bol JM, Mathijssen RH, Creemers GJ, et al. A CYP3A4 phenotype-based dosing algorithm for individualized treatment of irinotecan. Clin. Cancer Res 2010;16(2):736-742. [PubMed: 20068078]

25. Innocenti F, Ratain MJ. Irinotecan treatment in cancer patients with UGT1A1 polymorphisms. Oncology (Williston Park) 2003;17(5 Suppl. 5):52-55. [PubMed: 12800608]

26. Beutler E, Gelbart T, Demina A. Racial variability in the UDP-glucuronosyltransferase 1 (UGT1A1) promoter: a balanced polymorphism for regulation of bilirubin metabolism? Proc. Natl Acad. Sci. USA 1998;95(14):8170-8174. [PubMed: 9653159]

27. Ando Y, Saka H, Ando M, et al. Polymorphisms of UDP-glucuronosyltransferase gene and irinotecan toxicity: a pharmacogenetic analysis. Cancer Res 2000;60(24):6921-6926. [PubMed: $11156391]$ 
28. Guillemette C, Millikan RC, Newman B, Housman DE. Genetic polymorphisms in uridine diphospho-glucuronosyltransferase 1A1 and association with breast cancer among African Americans. Cancer Res 2000;60(4):950-956. [PubMed: 10706110]

29. Hall D, Ybazeta G, Destro-Bisol G, Petzl-Erler ML, Di Rienzo A. Variability at the uridine diphosphate glucuronosyltransferase $1 \mathrm{~A} 1$ promoter in human populations and primates. Pharmacogenetics 1999;9(5):591-599. [PubMed: 10591539]

30. Iyer L, Hall D, Das S, et al. Phenotype-genotype correlation of in vitro SN-38 (active metabolite of irinotecan) and bilirubin glucuronidation in human liver tissue with UGT1A1 promoter polymorphism. Clin. Pharmacol. Ther 1999;65(5):576-582. [PubMed: 10340924]

31. Iyer L, Das S, Janisch L, et al. UGT1A1*28 polymorphism as a determinant of irinotecan disposition and toxicity. Pharmacogenomics J 2002;2(1):43-47. [PubMed: 11990381]

32. McLeod HL, Sargent DJ, Marsh S, et al. Pharmacogenetic predictors of adverse events and response to chemotherapy in metastatic colorectal cancer; results from Intergroup Trial N9741. J. Clin. Oncol. 2010 DOI: 10.1200/JCO.2009.21.7943. (Epub ahead of print).

33. Innocenti F, Undevia SD, Iyer L, et al. Genetic variants in the UDP-glucuronosyltransferase 1A1 gene predict the risk of severe neutropenia of irinotecan. J. Clin. Oncol 2004;22(8):1382-1388. [PubMed: 15007088] — Prospective study confirming the role of UGT1AI*28 in irinotecan toxicity.

34. Staessen JA, Kuznetsova T, Acceto R, et al. on behalf of the OASIS-HT Investigators: FDA clears Third Wave pharmacogenetic test. Pharmacogenomics 2005;6(7):671-672.

35. Ratain MJ. From bedside to bench to bedside to clinical practice: an odyssey with irinotecan. Clin. Cancer Res 2006;12(6):1658-1660. [PubMed: 16551845]

36. Marsh S, van Rooij T. Challenges of incorporating pharmacogenomics into clinical practice. Gastrointest. Cancer Res 2009;3(5):206-207. [PubMed: 20084163]

37. Ratain MJ, Innocenti F. Individualizing dosing of irinotecan. Clin. Cancer Res 2010;16(2):371372. [PubMed: 20068075]

38. Hoskins JM, Goldberg RM, Qu P, Ibrahim JG, McLeod HL. UGT1A1*28 genotype and irinotecaninduced neutropenia: dose matters. J. Natl Cancer Inst 2007;99(17):1290-1295. [PubMed: $17728214]$ analysis showing that $U G T 1 A 1 * 28$-related irinotecan toxicity is dependent on irinotecan dose.

39. Schulz C, Heinemann V, Schalhorn A, et al. UGT1A1 gene polymorphism: impact on toxicity and efficacy of irinotecan-based regimens in metastatic colorectal cancer. World J. Gastroenterol 2009;15(40):5058-5066. [PubMed: 19859999]

40. Toffoli G, Cecchin E, Gasparini G, et al. Genotype-driven Phase I study of irinotecan administered in combination with fluorouracil/leucovorin in patients with metastatic colorectal cancer. J. Clin. Oncol 2010;28(5):866-871. [PubMed: 20038727] m Identifies the optimum dose of irinotecan based on genotype.

41. Hazama S, Nagashima A, Kondo H, et al. Phase I study of irinotecan and doxifluridine for metastatic colorectal cancer focusing on the UGT1AI*28 polymorphism. Cancer Sci 2010;101(3): 722-727. [PubMed: 20028383]

42. Premawardhena A, Fisher CA, Liu YT, et al. The global distribution of length polymorphisms of the promoters of the glucuronosyltransferase 1 gene (UGT1A1): hematologic and evolutionary implications. Blood Cells Mol. Dis 2003;31(1):98-101. [PubMed: 12850492]

43. Innocenti F, Undevia SD, Rosner GL, et al. Irinotecan (CPT-11) pharmacokinetics (PK) and neutropenia: interaction among UGT1A1 and transporter genes. Proc. Am. Soc. Clin. Oncol 2005;23:S16. (Abstract 2006).

44. Sai K, Saeki M, Saito Y, et al. UGT1A1 haplotypes associated with reduced glucuronidation and increased serum bilirubin in irinotecan-administered Japanese patients with cancer. Clin. Pharmacol. Ther 2004;75(6):501-515. [PubMed: 15179405]

45. Hoskins JM, Mcleod HL. The move from pharmacokinetics to pharmacodynamics. Curr. Pharmacogenomics 2006;4:39-46.

46. de Jong FA, Scott-Horton TJ, Kroetz DL, et al. Irinotecan-induced diarrhea: functional significance of the polymorphic $A B C C 2$ transporter protein. Clin. Pharmacol. Ther 2007;81(1):42-49. [PubMed: 17185998] 
47. Han JY, Lim HS, Shin ES, et al. Comprehensive analysis of UGT1A polymorphisms predictive for pharmacokinetics and treatment outcome in patients with non-small-cell lung cancer treated with irinotecan and cisplatin. J. Clin. Oncol 2006;24(15):2237-2244. [PubMed: 16636344]

48. Takano M, Kato M, Yoshikawa T, et al. Clinical significance of UDP-glucuronosyltransferase $1 \mathrm{~A} 1 * 6$ for toxicities of combination chemotherapy with irinotecan and cisplatin in gynecologic cancers: a prospective multi-institutional study. Oncology 2009;76(5):315-321. [PubMed: 19299905]

49. Jada SR, Lim R, Wong CI, et al. Role of $U G T 1 A 1 * 6, U G T 1 A 1 * 28$ and $A B C G 2$ c. $421 \mathrm{C}>\mathrm{A}$ polymorphisms in irinotecan-induced neutropenia in Asian cancer patients. Cancer Sci 2007;98(9): 1461-1467. [PubMed: 17627617]

50. Onoue M, Terada T, Kobayashi M, et al. UGT1A1*6 polymorphism is most predictive of severe neutropenia induced by irinotecan in Japanese cancer patients. Int. J. Clin. Oncol 2009;14(2):136142. [PubMed: 19390945]

51. Saito Y, Sai K, Maekawa K, et al. Close association of UGT1A9 IVS1+399C>T with UGT1A1*28, $* 6$, or $* 60$ haplotype and its apparent influence on 7-ethyl-10-hydroxycamptothecin (SN-38) glucuronidation in Japanese. Drug Metab. Dispos 2009;37(2):272-276. [PubMed: 18981166]

52. Carlini LE, Meropol NJ, Bever J, et al. UGTIA7 and UGT1A9 polymorphisms predict response and toxicity in colorectal cancer patients treated with capecitabine/irinotecan. Clin. Cancer Res 2005;11(3):1226-1236. [PubMed: 15709193]

53. Hoskins JM, McLeod HL. UGT1A and irinotecan toxicity: keeping it in the family. J. Clin. Oncol 2009;27(15):2419-2421. [PubMed: 19364959]

54. Cecchin E, Innocenti F, D'Andrea M, et al. Predictive role of the UGT1A1, UGT1A7, and UGT1A9 genetic variants and their haplotypes on the outcome of metastatic colorectal cancer patients treated with fluorouracil, leucovorin, and irinotecan. J. Clin. Oncol 2009;27(15):2457-2465. [PubMed: 19364970]

55. Sparreboom A, Danesi R, Ando Y, Chan J, Figg WD. Pharmacogenomics of ABC transporters and its role in cancer chemotherapy. Drug Resist. Update 2003;6(2):71-84.

56. Mathijssen RH, Marsh S, Karlsson MO, et al. Irinotecan pathway genotype analysis to predict pharmacokinetics. Clin. Cancer Res 2003;9(9):3246-3253. [PubMed: 12960109]

57. Lara PN Jr, Natale R, Crowley J, et al. Phase III trial of irinotecan/cisplatin compared with etoposide/cisplatin in extensive-stage small-cell lung cancer: clinical and pharmacogenomic results from SWOG S0124. J. Clin. Oncol 2009;27(15):2530-2535. [PubMed: 19349543]

58. Sai K, Kaniwa N, Itoda M, et al. Haplotype analysis of $A B C B 1 / M D R 1$ blocks in a Japanese population reveals genotype-dependent renal clearance of irinotecan. Pharmacogenetics 2003;13(12):741-757. [PubMed: 14646693]

59. Glimelius B, Garmo H, Berglund A, et al. Prediction of irinotecan and 5-fluorouracil toxicity and response in patients with advanced colorectal cancer. Pharmacogenomics J. 2010 DOI: 10.1038/ tpj.2010.10. (Epub ahead of print).

60. Han JY, Lim HS, Park YH, Lee SY, Lee JS. Integrated pharmacogenetic prediction of irinotecan pharmacokinetics and toxicity in patients with advanced non-small cell lung cancer. Lung Cancer 2009;63(1):115-120. [PubMed: 18221820]

61. Han JY, Lim HS, Yoo YK, et al. Associations of $A B C B 1, A B C C 2$, and $A B C G 2$ polymorphisms with irinotecan-pharmacokinetics and clinical outcome in patients with advanced non-small cell lung cancer. Cancer 2007;110(1):138-147. [PubMed: 17534875]

62. Fujita K, Nagashima F, Yamamoto W, et al. Association of ATP-binding cassette, sub-family C, number $2(A B C C 2)$ genotype with pharmacokinetics of irinotecan in Japanese patients with metastatic colorectal cancer treated with irinotecan plus infusional 5-fluorouracil/leucovorin (FOLFIRI). Biol. Pharm. Bull 2008;31(11):2137-2142. [PubMed: 18981587]

63. Innocenti F, Kroetz DL, Schuetz E, et al. Comprehensive pharmacogenetic analysis of irinotecan neutropenia and pharmacokinetics. J. Clin. Oncol 2009;27(16):2604-2614. [PubMed: 19349540]

64. Schellens JH, Maliepaard M, Scheper RJ, et al. Transport of topoisomerase I inhibitors by the breast cancer resistance protein. Potential clinical implications. Ann. NY Acad. Sci 2000;922:188194. [PubMed: 11193894] 
65. Candeil L, Gourdier I, Peyron D, et al. ABCG2 overexpression in colon cancer cells resistant to SN38 and in irinotecan-treated metastases. Int. J. Cancer 2004;109(6):848-854. [PubMed: 15027118]

66. Imai Y, Nakane M, Kage K, et al. C421A polymorphism in the human breast cancer resistance protein gene is associated with low expression of Q141K protein and low-level drug resistance. Mol. Cancer Ther 2002;1(8):611-616. [PubMed: 12479221]

67. Sai K, Saito Y, Maekawa K, et al. Additive effects of drug transporter genetic polymorphisms on irinotecan pharmacokinetics/pharmacodynamics in Japanese cancer patients. Cancer Chemother. Pharmacol 2009;66(1):95-105. [PubMed: 19771428]

68. Park DJ, Stoehlmacher J, Zhang W, Tsao-Wei DD, Groshen S, Lenz HJ. A Xeroderma pigmentosum group $\mathrm{D}$ gene polymorphism predicts clinical outcome to platinum-based chemotherapy in patients with advanced colorectal cancer. Cancer Res 2001;61(24):8654-8658. [PubMed: 11751380]

69. Chatterjee S, Cheng MF, Trivedi D, Petzold SJ, Berger NA. Camptothecin hypersensitivity in poly(adenosine diphosphate-ribose) polymerase-deficient cell lines. Cancer Commun 1989;1(6): 389-394. [PubMed: 2562007]

70. Pouliot JJ, Yao KC, Robertson CA, Nash HA. Yeast gene for a Tyr-DNA phosphodiesterase that repairs topoisomerase I complexes. Science 1999;286(5439):552-555. [PubMed: 10521354]

71. Reid RJ, Fiorani P, Sugawara M, Bjornsti MA. CDC45 and DPB11 are required for processive DNA replication and resistance to DNA topoisomerase I-mediated DNA damage. Proc. Natl Acad. Sci. USA 1999;96(20):11440-11445. [PubMed: 10500195]

72. Cusack JC Jr, Liu R, Houston M, et al. Enhanced chemosensitivity to CPT-11 with proteasome inhibitor PS-341: implications for systemic nuclear factor- $\kappa B$ inhibition. Cancer Res 2001;61(9): 3535-3540. [PubMed: 11325813]

73. Valente P, Arzani D, Cesario A, Margaritora S, Carbone E, Russo P. TNF increases camptothecininduced apoptosis by inhibition of NF-кB. Eur. J. Cancer 2003;39(10):1468-1477. [PubMed: 12826051]

74. Hoskins JM, Marcuello E, Altes A, et al. Irinotecan pharmacogenetics: influence of pharmacodynamic genes. Clin. Cancer Res 2008;14(6):1788-1796. [PubMed: 18347181]

75. Hoskins JM, Rosner GL, Ratain MJ, McLeod HL, Innocenti F. Pharmacodynamic genes do not influence risk of neutropenia in cancer patients treated with moderately high-dose irinotecan. Pharmacogenomics 2009;10(7):1139-1146. [PubMed: 19604089]

76. Braun MS, Richman SD, Thompson L, et al. Association of molecular markers with toxicity outcomes in a randomized trial of chemotherapy for advanced colorectal cancer: the FOCUS trial. J. Clin. Oncol 2009;27(33):5519-5528. [PubMed: 19858398]

77. Artac M, Bozcuk H, Pehlivan S, et al. The value of XPD and XRCC1 genotype polymorphisms to predict clinical outcome in metastatic colorectal carcinoma patients with irinotecan-based regimens. J. Cancer Res. Clin. Oncol 2009;136(6):803-809. [PubMed: 19908066]

78. Gold HT, Hall MJ, Blinder V, Schackman BR. Cost effectiveness of pharmacogenetic testing for uridine diphosphate glucuronosyltransferase $1 \mathrm{~A} 1$ before irinotecan administration for metastatic colorectal cancer. Cancer 2009;115(17):3858-3867. [PubMed: 19517472] ש Pharmacoeconomic evaluation of $U G T 1 A 1 * 28$ genotype screening.

79. Raynal C, Pascussi JM, Leguelinel G, et al. Pregnane X receptor (PXR) expression in colorectal cancer cells restricts irinotecan chemosensitivity through enhanced SN-38 glucuronidation. Mol. Cancer 2010;9:46. [PubMed: 20196838]

80. Belanger AS, Tojcic J, Harvey M, Guillemette C. Regulation of UGT1A1 and HNF1 transcription factor gene expression by DNA methylation in colon cancer cells. BMC Mol. Biol 2010;11:9. [PubMed: 20096102]

81. Klein TE, Chang JT, Cho MK, et al. Integrating genotype and phenotype information: an overview of the PharmGKB project. Pharmacogenetics Research Network and Knowledge Base. Pharmacogenomics J 2001;1(3):167-170. [PubMed: 11908751] 


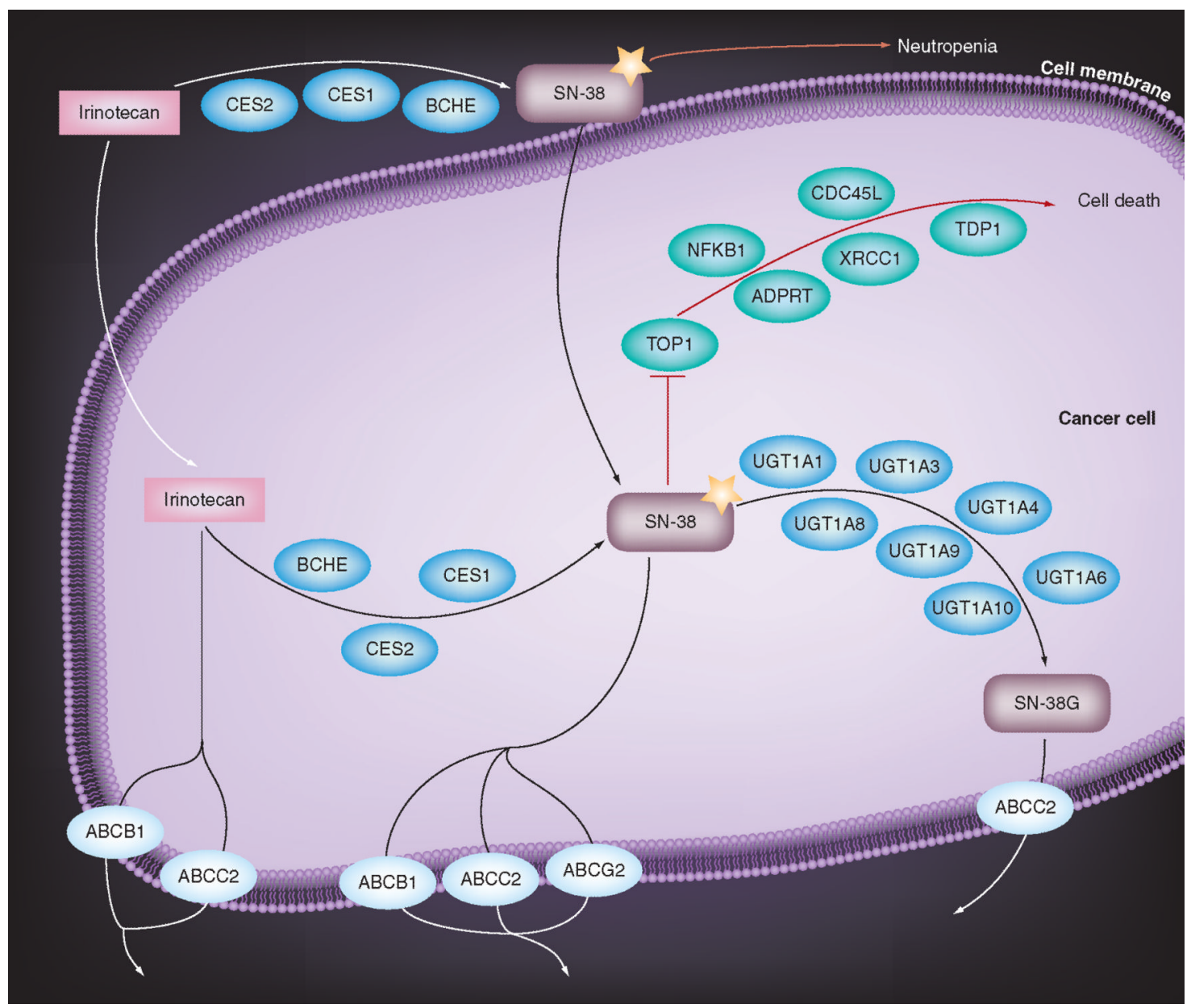

Figure 1. Irinotecan cancer cell pathway

Reproduced with kind permission from PharmGKB and Stanford University [81]. 


\section{Table 1}

Summary of genes and variants from irinotecan pharmacogenomics studies.

\begin{tabular}{|c|c|c|c|c|}
\hline Gene & Variant & dbSNP ID & Effect & Ref. \\
\hline$A B C B 1$ & $1236 \mathrm{C}>\mathrm{T}$ & rs1128503 & $\begin{array}{l}\text { Decreased irinotecan clearance; } \\
\text { risk of toxicity and reduced } \\
\text { survival when in haplotype with } \\
2677 \text { and } 3435\end{array}$ & {$[56,58,59]$} \\
\hline$A B C B 1$ & $2677 \mathrm{G}>\mathrm{A} / \mathrm{T}$ & rs2032582 & $\begin{array}{l}\text { Risk of toxicity and reduced } \\
\text { survival when in haplotype with } \\
1236 \text { and } 3435\end{array}$ & {$[58,59]$} \\
\hline$A B C B 1$ & $3435 \mathrm{C}>\mathrm{T}$ & rs 1045642 & $\begin{array}{l}\text { Increased toxicity; risk of } \\
\text { toxicity and reduced survival } \\
\text { when in haplotype with } 1236 \\
\text { and } 2677\end{array}$ & [57-59] \\
\hline$A B C C 2$ & $-24 \mathrm{C}>\mathrm{T}$ & rs717620 & $\begin{array}{l}\text { Increased response and survival } \\
\text { with } 3972 \text {; toxicity as part of } \\
A B C C 2 \text { haplotype in patients } \\
\text { without } G T 1 A 1 * 28\end{array}$ & {$[46,61-63]$} \\
\hline$A B C C 2$ & $3972 \mathrm{~T}>\mathrm{C}$ & rs3740066 & $\begin{array}{l}\text { Increased response and survival } \\
\text { with }-24 \text {; toxicity as part of } \\
A B C C 2 \text { haplotype in patients } \\
\text { without } U G T 1 A 1 * 28\end{array}$ & {$[43,46,60-63]$} \\
\hline$A B C G 2$ & $34 \mathrm{G}>\mathrm{A}$ & rs2231137 & $\begin{array}{l}\text { Increased toxicity; no } \\
\text { association with toxicity and } \\
\text { outcome }\end{array}$ & {$[60,61]$} \\
\hline$A B C G 2$ & $421 \mathrm{C}>\mathrm{A} ; \mathrm{Q} 141 \mathrm{~K}$ & rs 2231142 & $\begin{array}{l}\text { Reduced expression; irinotecan } \\
\text { resistance; toxicity with IVS12 } \\
+49 \mathrm{G}>\mathrm{T}\end{array}$ & {$[49,61,66,67]$} \\
\hline$A B C G 2$ & IVS12+49G $>\mathrm{T}$ & rs3832043 & Toxicity with $421 \mathrm{C}>\mathrm{A}$ & {$[49,61,66,67]$} \\
\hline CES1 & $-816 \mathrm{~A}>\mathrm{C}$ & Unknown & Altered $C E S 1$ promoter activity & [22] \\
\hline CES2 & $830 \mathrm{C}>\mathrm{G} ;-171 \mathrm{C}>\mathrm{G}$ & rs11075646 & $\begin{array}{l}\text { No association with expression, } \\
\text { catalytic activity, toxicity or } \\
\text { outcome }\end{array}$ & [20] \\
\hline СYР3A4 & Activity & & $\begin{array}{l}\text { Altered irinotecan dosing } \\
\text { requirement }\end{array}$ & [24] \\
\hline$N R 112$ & Expression & & Altered SN-38 glucuronidation & [79] \\
\hline$T D P 1$ & IVS12+79T $>\mathrm{G}$ & rs2401863 & $\begin{array}{l}\text { Response; no toxicity } \\
\text { association at higher doses }\end{array}$ & {$[74,75]$} \\
\hline UGT1A1 & $-3156 \mathrm{G}>\mathrm{A}$ & rs10929302 & Increased risk of toxicity & {$[32,33]$} \\
\hline UGT1A1 & $(\mathrm{TA})_{7} \mathrm{TAA}, * 28$ & rs8175347 & $\begin{array}{l}\text { Increased risk of toxicity; dose } \\
\text { dependent }\end{array}$ & {$[32,33,38-41]$} \\
\hline UGT1A1 & $\mathrm{G} 71 \mathrm{R}, * 6$ & rs4148323 & Increased risk of toxicity & {$[44,47]$} \\
\hline UGT1A7 & $* 2(\mathrm{~N} 129 \mathrm{~K}$ and $\mathrm{R} 131 \mathrm{~K})$ & rs17868323, rs17868324 & SN-38 glucuronidation; response & {$[47,52]$} \\
\hline UGT1A7 & *3 (N129K, R131K and W208R) & rs17868323, rs17868324, rs11692021 & $\begin{array}{l}\text { SN-38 glucuronidation; } \\
\text { increased risk of toxicity; altered } \\
\text { response }\end{array}$ & {$[47,52,54]$} \\
\hline UGT1A9 & $-118(\mathrm{dT})$ & rs 3832043 & SN-30 glucuronidation; response & {$[44,47,52,54]$} \\
\hline$X R C C 1$ & Haplotype (-1149delGGCC, R399Q) & rs321329 rs25487 & Response & [74] \\
\hline$X R C C 1$ & R399Q & rs 25487 & $\begin{array}{l}\text { No association with toxicity; } \\
\text { association with response }\end{array}$ & {$[76,77]$} \\
\hline
\end{tabular}

dbSNP: SNP database 